\title{
A comparison of the antigenicity of soya-bean-based infant formulas
}

\author{
BY L. M. J. HEPPELL, J. W. SISSONS AND H. E. PEDERSEN* \\ AFRC Institute for Grassland and Animal Production, Church Lane, Shinfield, \\ Reading RG2 9AQ, Berkshire
}

\section{(Received 28 October 1986 - Accepted 28 May 1987)}

1. The antigenicity of four soya-bean-based infant formulas (Prosobee powder, Prosobee liquid concentrate (Mead Johnson, Uxbridge, Middx), Wysoy (Wyeth, Maidenhead, Berks) and Formula S (Cow and Gate, Trowbridge, Wilts)) was measured by enzyme-linked immunosorbent assays (ELISAs) specific for glycinin and $\beta$-conglycinin. Results were compared with in vivo assessments of antigenicity using guinea-pigs, rabbits and calves.

2. The levels of antigenic glycinin and $\beta$-conglycinin in Wysoy and Formula $S$ were below the limits of detection of the ELISA. Both these proteins were detected in Prosobee powder and Prosobee liquid concentrate with the highest levels, especially for glycinin, being present in Prosobee powder.

3. Wysoy was sufficiently antigenic to evoke a soya-bean-specific serum antibody response in rabbits injected with this formula emulsified in complete Freunds adjuvant. A significantly greater response was obtained when rabbits were similarly injected with Prosobee powder.

4. The formulas varied in their ability to sensitize guinea-pigs for both anaphylaxis and antibody production when given orally, although the differences were not statistically significant. Prosobee powder appeared to be the most antigenic and Formula $S$ the least, with Prosobee liquid concentrate and Wysoy being intermediate.

5. Similar variations in antigenicity were observed when Prosobee powder, Wysoy and Formula $\mathrm{S}$ were fed to soya-bean-sensitive calves. These formulas were all capable of provoking intestinal disturbances (seen as increased ileal flow-rate, decreased small intestinal transit time and decreased nitrogen absorption) but the most severe reactions were seen when Prosobee powder was fed and the least with Formula $S$.

6. Thus the four soya-bean-based infant formulas showed considerable differences in antigenicity. In vivo studies using guinea-pigs, rabbits and calves were in good agreement and broadly correlated with the immunochemical assessment of antigenicity. However, the in vitro and in vivo results did not correspond exactly and levels of glycinin and $\beta$-conglycinin below the limit of detection by ELISA could evoke an immune response in the different animal species. We believe that these variations in antigenicity of different commercial products prepared from isolated soya-bean protein may be important when interpreting the results from studies of the development of allergy in infants given soya-bean-based formulas.

Soya-bean-based infant formulas are often recommended for babies who have developed cow's-milk-protein intolerance, but some of these infants then develop hypersensitivity reactions to the soya-bean-protein (Halpin et al. 1977; Powell, 1978; Perkkiö et al. 1981). It has been suggested that feeding soya-bean rather than cow's milk from birth results in a lower incidence of allergic disease (Glaser \& Johstone, 1953) but this has been disputed by a number of authors (Halpern et al. 1973; Kjellman \& Johansson, 1979). There is some evidence that soya-bean protein may be less antigenic than cow's-milk protein (Halpern et al. 1973; May et al. 1982). However, the situation is not clear since from studies of the serum antibody response of babies given soya-bean or cow's-milk-based formulas, Eastham et al. (1978) concluded that soya-bean protein is as least as antigenic as cow's-milk protein. Commercial infant formulas based on cow's-milk protein that have received severe heat treatment during manufacture appear to be less antigenic than mildly heated preparations (McLaughlan et al. 1981) and heat treatment of whey protein has been proposed as a possible method of producing a hypoallergenic infant formula (Heppell et al. 1984). Differing processing methods have been shown to affect the antigenicity of soyabean-protein-based milk substitutes for preruminant calves (Sissons et al. 1979). Ratner et al. (1955) found that the antigenicity of soya bean in an infant formula based on soya-bean

\footnotetext{
* Present address: Aarhus Oliefabrik A/S, M.P. Bruunsgade 27, DK-8000, Aarhus, Denmark.
} 
flour had been reduced by heat treatment. The soya-bean-based infant formulas currently available contain soya bean in the form of a protein isolate, rather than soya-bean flour. These formulas are likely to have undergone differing processing methods, both during production of the soya-bean isolate and during manufacture of the formula itself. It is conceivable that this might result in differences in the antigenicity of different formulas, and such variations could be very important when interpreting the results of clinical trials. In the present paper we examine the antigenicity of four commercially available soya-beanbased infant formulas and compare results obtained by immunochemical assay and in vivo studies.

\section{MATERIALS AND METHODS}

\section{Animals}

Guinea-pigs. Male Dunkin Hartley guinea-pigs (Porcellus Ltd, Heathfield, Sussex) were used for the feeding experiments when they were 4-5 weeks old. Animals were maintained on batches of FDl diet (Labsure, Poole, Dorset) that had been shown to be soya-bean-free by immunological testing. Water and hay were given ad lib.

Rabbits. New Zealand White rabbits were obtained from Ranch Rabbits Ltd (Capthorn, Sussex). R17 rabbit pellets (Labsure) and water were given ad lib.

Calves. Three Friesian bull calves were given colostrum for $4 \mathrm{~d}$ after birth, and were then fed twice daily on cow's milk. At 3 weeks of age they were equipped with a simple cannula in the fundic region of the abomasum and a re-entrant cannula in the distal ileum near the ileo-caecal junction (Sissons \& Smith, 1976).

\section{Infant milk formulas}

Prosobee powder, Prosobee liquid concentrate (Mead Johnson, Uxbridge, Middx), Wysoy (Wyeth, Maidenhead, Berks) and Formula S (Cow and Gate, Trowbridge, Wilts) were compared in our study. These are all soya-bean-based infant formulas which are commercially available in the UK. SMA (Wyeth), a cow's milk-based formula, was used as a treatment control in the calf experiments.

\section{Antigens}

The $11 \mathrm{~S}$ and $7 \mathrm{~S}$ soya-bean globulins, glycinin and $\beta$-conglycinin, were isolated as described by Kilshaw \& Sissons (1979a). Dosoy (British Arkady, Manchester) consisted of unheated ground soya-bean endosperm and was considered to contain the full spectrum of soya-bean constituents in undenatured form. The Dosoy was defatted by extraction with light petroleum spirit (b.p. $40-60^{\circ}$ ) at room temperature. An extract was prepared by stirring $1 \mathrm{~g}$ with $20 \mathrm{ml}$ saline $(9 \mathrm{~g}$ sodium chloride/1) at room temperature for $1 \mathrm{~h}$. Insoluble material was removed by centrifugation.

\footnotetext{
Antisera

Antisera to glycinin and $\beta$-conglycinin were prepared in rabbits (Kilshaw \& Sissons, $1979 a)$. Rabbit anti-bovine IgG, rabbit anti-guinea-pig IgG and alkaline phosphatase $(E C$ 3.1.3.1)-conjugated goat anti-rabbit IgG were obtained from Miles Laboratories (Slough, Bucks).

Assessment of antigenicity of infant formulas by parenteral injection

Groups of three rabbits were given intramuscular injections of Wysoy, Prosobee powder or Dosoy emulsified in complete Freunds adjuvant (CFA). The emulsion ( $2 \mathrm{ml}$ ), containing approximately $15 \mathrm{mg}$ protein, was divided equally between four sites on the hind- and forelimbs. The animals were boosted with the same dose of antigen in CFA 4 weeks later and blood samples were taken after a further 3 weeks.
} 


\section{Feeding experiments}

Guinea-pigs. Blood samples were taken from all animals by cardiac puncture before the trial. The serum was assayed for soya-bean-specific antibodies to ensure that there had been no previous contact with soya-bean. The soya-bean-based infant formulas were prepared as recommended for infant feeding at a protein concentration of $21 \mathrm{~g} / 1$ and groups of five guinea-pigs were given these products to drink for 2 weeks (each animal consumed about 0.1 litres $/ \mathrm{d}$ ). The formulas were then replaced by water and $7 \mathrm{~d}$ later further blood samples were taken and assayed for soya-bean-specific antibodies. The next day the animals were tested for systemic anaphylaxis by intravenous injection with $0.5 \mathrm{ml}$ of a centrifuged sample of the formula that they had been drinking.

Calves. The calves were reared on cow's milk until 3 weeks after surgery. Subsequently the animals were sensitized to soya-bean protein by giving a series of five experimental liquid feeds containing heated soya-bean flour (Sissons \& Smith, 1976; Kilshaw \& Sissons, $1979 \mathrm{~b}$ ). These feeds were given by direct infusion into the abomasum at intervals of 2-3 $\mathrm{d}$. The calves were then challenged with further liquid feeds in which the protein was derived from Prosobee powder, Wysoy, Formula S or SMA (the latter was a cow's-milkbased formula used as a control). These feeds were prepared by reconstituting the powdered formula with water at a protein concentration of $21.0 \mathrm{~g} / \mathrm{l}$, as recommended by the manufacturers for feeding to human infants. Phenol red $(0 \cdot 1 \mathrm{~g})$ and polyethylene glycol $(5 \mathrm{~g})$ were added to each feed as markers. The order of giving the feeds was in accordance with a Latin-square design. The results of this trial showed differences between the products, but for some measurements the distinction was not clear. Thus, the trial was repeated, first at a reduced protein concentration of $4 \cdot 2 \mathrm{~g} / 1$ and then at the previous level of $21.0 \mathrm{~g} / 1$. In each of the subsequent trials the Latin-square design was re-randomized. For each feed, the volume (2.7 litres) and energy density $(2800 \mathrm{~kJ} / 1)$ was maintained since variations in these two factors are known to affect rates of digesta passage from the stomach (Hunt \& Stubbs, 1975; Sissons, 1983). Adjustments of energy density were made with additions of glucose. After giving an experimental feed, digesta were collected from the distal ileum for a period of $21 \mathrm{~h}$ following the arrival of the phenol red marker. Measurement of small intestinal transit time, mean rates of ileal digesta flow and net disappearance of nitrogen between the abomasum and ileum were made as described by Sissons \& Smith (1976).

\section{Antibody measurements}

The levels of soya-bean-specific IgG antibodies in guinea-pig or calf sera were assessed by an enzyme-linked immunosorbent assay (ELISA) based on the methods described by Voller et al. (1976). Briefly, microtitre plates were coated with the purified soya-bean globulins or with extracts of the four infant formulas or the Dosoy extract. They were incubated with doubling dilutions of test sera starting at $1 / 20$. This was followed by washing and incubation with rabbit anti-guinea-pig IgG or anti-bovine IgG, and then alkaline phosphatase-conjugated goat anti-rabbit IgG. After addition of the enzyme substrate (disodium nitrophenyl phosphate) and incubation at room temperature, the optical density at $410 \mathrm{~nm}$ was read. Antibody titres were expressed as the highest number of doubling dilutions giving an optical density of 0.1 above background. The assay for soya-bean-specific antibodies in rabbit sera was similar except that the second antibody was not required since the enzyme conjugate was anti-rabbit IgG.

\section{Determination of antigenic soya-bean protein in the infant formula}

The level of antigenic glycinin and $\beta$-conglycinin was measured by a competitive inhibition ELISA (Heppell, 1985). Serial four fold dilutions of test sample were incubated with a 


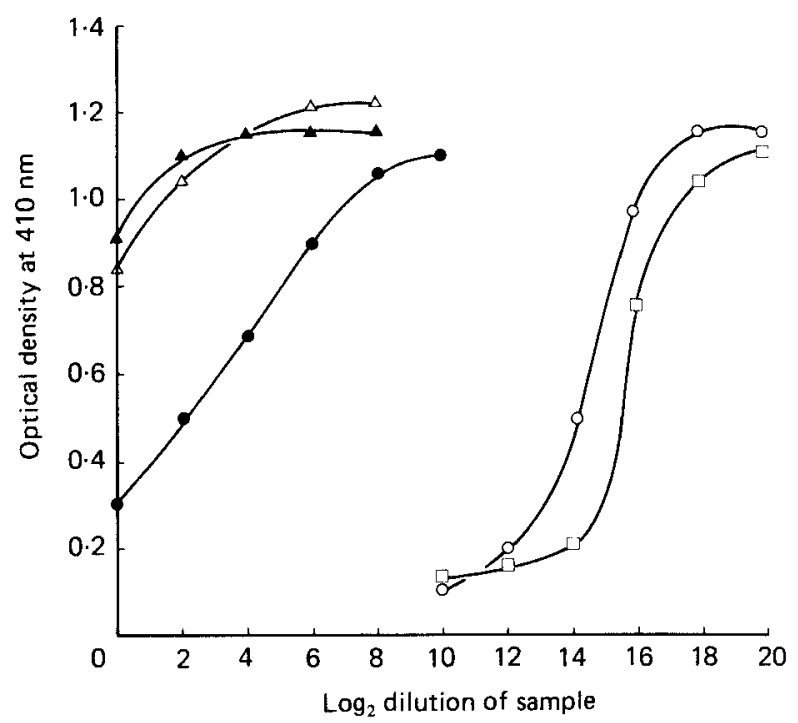

Fig. 1. Competitive inhibition enzyme-linked immunosorbent assay to measure the levels of glycinin in Prosobee powder (Mead Johnson) (O), Prosobee liquid concentrate (Mead Johnson) (O), Wysoy (Wyeth) $(\triangle)$ and Formula $S$ (Cow and Gate) $(\boldsymbol{\Delta})$, showing $1 / 2,1 / 4096$, less than $1 / 65536$ and less than 1/65536 respectively of the level of undenatured glycinin in Dosoy (British Arkady) ( $\square$ ).

standard dilution of rabbit antiserum to the test protein, and residual unbound antibodies were quantified by ELISA. The samples were assayed in parallel with a standard (the Dosoy extract) and the number of doubling dilutions separating the mid-points of their respective assay curves was determined (Fig. 1). The level of antigenic soya-bean protein in the infant formulas was expressed as a proportion, to the nearest doubling dilution, of the level in Dosoy.

\section{Statistics}

Treatment differences in experiments with rabbits were compared by Student's $t$ test. The in vitro study of native and processed antigens was analysed by paired $t$ tests and regression analysis. In experiments with calves the significance of treatment differences was examined by analysis of variance. No significant period effects were found between observations made in the first and third trials both using feeds with protein concentrations of $21.0 \mathrm{~g} / 1$. Consequently an analysis of variance of treatment differences was made on the combined results of the first and third Latin squares.

\section{RESULTS}

Immunoassay of antigenic glycinin and $\beta$-conglycinin in the infant formulas

Results given in Table 1 show that there were considerable differences between the levels of both antigenic glycinin and $\beta$-conglycinin in the four formulas. The levels of these proteins in Wysoy and Formula $S$ were below the limits of detection of the assay. Glycinin and $\beta$-conglycinin were detected in Prosobee powder and Prosobee liquid concentrate with the highest levels, especially for glycinin, being present in Prosobee powder.

\section{Anaphylaxis in guinea-pigs drinking the soya-bean-based infant formulas}

The formulas differed in their anaphylactic sensitizing capacities, Prosobee powder being the most sensitizing and Formula $S$ the least (Table 2). However, the number of animals reacting was low and the differences between the formulas were not very marked. Groups 
Table 1. Antigenic glycinin and $\beta$-conglycinin in soya-bean-based infant formulas assessed by a competitive inhibition ELISA

(Proportion of values for Dosoy standard)

\begin{tabular}{lcc}
\multicolumn{1}{c}{ Infant formula } & Glycinin & $\beta$-Conglycinin \\
\hline Prosobee powder (Mead Johnson) & $1 / 2$ & $1 / 512$ \\
Prosobee liquid concentrate (Mead Johnson) & $1 / 4096$ & $1 / 2048$ \\
Wysoy (Wyeth) & $<1 / 65536$ & $<1 / 16384$ \\
Formula S (Cow and Gate) & $<1 / 65536$ & $<1 / 16384$ \\
\hline
\end{tabular}

ELISA, enzyme-linked immunosorbent assay.

Table 2. Anaphylactic sensitivity in guinea-pigs drinking soya-bean-based infant formulas

\begin{tabular}{lcccc}
\hline Product fed... & $\begin{array}{c}\text { Prosobee powder } \\
\text { (Mead Johnson) }\end{array}$ & $\begin{array}{c}\text { Prosobee liquid } \\
\text { concentrate } \\
\text { (Mead Johnson) }\end{array}$ & $\begin{array}{c}\text { Wysoy } \\
\text { (Wyeth) }\end{array}$ & $\begin{array}{c}\text { Formula } S \\
\text { (Cow and Gate) }\end{array}$ \\
\hline Guinea-pigs showing anaphylaxis* & $2(1)$ & 1 & $1(1)$ & 0 \\
\hline
\end{tabular}

* In groups of five. Anaphylaxis following intravenous injection of product fed (number fatal in parentheses).

Table 3. Antibody production in guinea-pigs drinking soya-bean-based infant formulas

(Mean values with their standard errors. The no. of animals in a group giving positive results, i.e. $\operatorname{IgG}$ titres $>1 / 20$, is shown in parentheses)

\begin{tabular}{|c|c|c|c|c|c|c|}
\hline \multirow[b]{3}{*}{ Product fed } & \multicolumn{6}{|c|}{ Serum antibodies* (IgG titres) to: } \\
\hline & \multicolumn{2}{|c|}{ Whole soya bean } & \multicolumn{2}{|c|}{ Glycinin } & \multicolumn{2}{|c|}{$\beta$-Conglycinin } \\
\hline & Mean & SE & Mean & SE & Mean & SE \\
\hline $\begin{array}{l}\text { Prosobee powder } \\
\text { (Mead Johnson) }\end{array}$ & \multicolumn{2}{|c|}{$\begin{array}{l}3.8 \\
(5 / 5 \text { positive })\end{array}$} & \multicolumn{2}{|c|}{$\underset{(5 / 5 \text { positive })}{4 \cdot 2}$} & \multicolumn{2}{|c|}{ (3/5 positive) } \\
\hline $\begin{array}{l}\text { Prosobee liquid } \\
\text { concentrate } \\
\text { (Mead Johnson) }\end{array}$ & \multicolumn{2}{|c|}{ ( $4 / 5$ positive) } & \multicolumn{2}{|c|}{ (4/5 positive) } & \multicolumn{2}{|c|}{ ( $5 / 5$ positive) } \\
\hline Wysoy (Wyeth) & \multicolumn{2}{|c|}{ (4/5 positive) } & $\begin{array}{l}3 \cdot 2 \\
(4 / 5\end{array}$ & $\begin{array}{l}1 \cdot 2 \\
\text { ve) }\end{array}$ & \multicolumn{2}{|c|}{ ( $2 / 5$ positive) } \\
\hline $\begin{array}{l}\text { Formula } S \\
\text { (Cow and Gate) }\end{array}$ & $\begin{array}{l}1 \cdot 2 \\
(2 / 5\end{array}$ & $\begin{array}{l}0.7 \\
\text { ve) }\end{array}$ & $\begin{array}{l}1 \cdot 6 \\
(2 / 5\end{array}$ & $\begin{array}{l}1 \cdot 0 \\
\text { ve) }\end{array}$ & $\begin{array}{r}\text { Trace } \\
(1\end{array}$ & \\
\hline
\end{tabular}

\footnotetext{
* Serum antibody titres (no. of doubling dilutions starting with $1 / 20$ dilution of the original sample) were determined by enzyme-linked immunosorbent assay.

$\dagger$ Detectable, but just less than $1 / 20$.
}

of control animals which had not received dietary soya bean showed no reactions when injected with any of the formulas.

Antibody production in guinea-pigs drinking the soya-bean-based infant formulas IgG antibodies to the Dosoy extract were detected in the sera of all guinea-pigs drinking Prosobee powder, 4/5 drinking Prosobee liquid concentrate or Wysoy, and 2/5 drinking Formula $S$ (see Table 3). Differences in the average titres between the four groups of guinea- 
Table 4. Antibody production in rabbits injected with soya-bean-based products in complete Freunds adjuvant

(Mean values with their standard errors)

\begin{tabular}{|c|c|c|c|c|c|c|}
\hline \multirow[b]{3}{*}{ Product injected } & \multicolumn{6}{|c|}{ Serum antibodies* (IgG titres) to: } \\
\hline & \multicolumn{2}{|c|}{ Whole soya bean } & \multicolumn{2}{|c|}{ Glycinin } & \multicolumn{2}{|c|}{$\beta$-Conglycinin } \\
\hline & Mean & $\mathrm{SE}$ & Mean & SE & Mean & $\mathrm{SE}$ \\
\hline Dosoy (British Arkady) & $11 \cdot 8^{\mathrm{b}}$ & 0.3 & $10 \cdot 4^{\mathrm{b}}$ & 0.6 & $8 \cdot 5^{\mathrm{b}}$ & $0 \cdot 5$ \\
\hline $\begin{array}{l}\text { Prosobee powder (Mead } \\
\text { Johnson) }\end{array}$ & $11 \cdot 1^{\mathrm{b}}$ & $0 \cdot 5$ & $10 \cdot 6^{\mathrm{b}}$ & $0 \cdot 3$ & $8 \cdot 3^{3, b}$ & $0 \cdot 9$ \\
\hline Wysoy (Wyeth) & $7 \cdot 8^{\mathrm{a}}$ & $0 \cdot 4$ & $7 \cdot 6^{\mathrm{a}}$ & 0.5 & $6 \cdot 3^{a}$ & $0 \cdot 3$ \\
\hline
\end{tabular}

\footnotetext{
* Serum antibody titres (no. of doubling dilutions starting with $1 / 20$ dilution of the original sampie) were determined by enzyme-linked immunosorbent assay.

${ }^{a, b}$ Mean values in vertical columns with different superscript letters were significantly different $(P<0.02)$.
}

pigs were not significant, but showed the same trend with Prosobee powder evoking the highest antibody levels, and Formula $S$ the lowest. The antibody response to glycinin was very similar to that for whole soya bean. Again, Prosobee powder was the most sensitizing and Formula $S$ the least. Measurement of antibodies to $\beta$-conglycinin in sera from the four groups indicated that Prosobee liquid concentrate evoked the greatest response with all animals in this group producing specific antibody although the titres were low. Fewer animals reacted to Prosobee powder and Wysoy, and responses evoked by Formula $S$ were almost undetectable. An assessment was made of the binding of serum from the four groups of guinea-pigs to plates coated with the formula that they had received in their diet. Regression analysis showed a significant linear relation $(P<0.001)$ between individual antibody titres measured on Dosoy and on formula-coated plates. The mean (with SE) antibody titres on formula-coated plates were $4.4(1.4), 2.9(0.7), 2.5(0.9)$, and $0.4(0.4)$ for Prosobee powder, Prosobee liquid concentrate, Wysoy and Formula $S$ respectively. These values were not significantly different $(P<0.05$; paired $t$ test $)$ from the results obtained with Dosoy-coated plates (Table 3).

Antibody production in rabbits injected with soya-bean-based products emulsified in CFA Results given in Table 4 show that parenteral injection of Prosobee powder in CFA resulted in a systemic antibody response of a similar magnitude to that evoked by whole soya bean (Dosoy). Wysoy also induced a response in rabbits; however, the antibody titres to whole soya bean, glycinin and $\beta$-conglycinin were significantly lower than those obtained with Prosobee powder and Dosoy.

\section{Intestinal hypersensitivity reactions of soya-bean-sensitive calves fed on soya-bean-based infant formulas}

Calves used in the feeding experiment were shown to develop intestinal hypersensitivity reactions after receiving a series of liquid feeds containing heated soya-bean flour similar to the gut disorders described by Sissons \& Smith (1976). Briefly, following repeated feeds with heated soya-bean flour, increased ileal flow-rate, decreased small intestinal transit time and decreased $\mathbf{N}$ absorption were observed for all three animals compared with results obtained when they were given casein-based feeds. These disturbances in intestinal function were accompanied by a rise in soya-bean-specific antibody titres. Using Dosoy-coated 
Table 5. Effect of soya-bean-based infant formulas $(21 \mathrm{~g}$ protein $/ \mathrm{l})$ on digesta passage and nitrogen absorption in the small intestine of soya-bean-sensitive calves

(Mean values with their standard errors)

\begin{tabular}{|c|c|c|c|c|c|c|}
\hline \multirow[b]{2}{*}{ Product fed } & \multicolumn{2}{|c|}{$\begin{array}{l}\text { Small intestinal } \\
\text { transit time } \\
\text { (h) }\end{array}$} & \multicolumn{2}{|c|}{$\begin{array}{c}\text { Ileal flow-rate } \\
0-21 \mathrm{~h} \\
(\mathrm{~g} / \mathrm{h})\end{array}$} & \multicolumn{2}{|c|}{$\begin{array}{l}\text { Net } N \text { absorption } \\
(\% \text { of intake })\end{array}$} \\
\hline & Mean & $\mathrm{SE}$ & Mean & $\mathrm{SE}$ & Mean & SE \\
\hline $\begin{array}{l}\text { Prosobee powder (Mead } \\
\text { Johnson) }\end{array}$ & $2 \cdot 5^{b}$ & 0.3 & $127^{b}$ & 24 & $52^{\mathrm{c}}$ & 3 \\
\hline Wysoy (Wyeth) & $2 \cdot 3^{\mathrm{b}}$ & 0.3 & $100^{\mathrm{a}, \mathrm{b}}$ & 7 & $62^{\mathrm{b}}$ & 4 \\
\hline Formula S (Cow and Gate) & $2 \cdot 5^{\mathrm{b}}$ & $0 \cdot 2$ & $111^{b}$ & 5 & $66^{\mathrm{a}, \mathrm{b}}$ & 1 \\
\hline SMA (Wyeth; control) & $4 \cdot 2^{\mathrm{a}}$ & $0 \cdot 3$ & $53^{\mathrm{a}}$ & 12 & $73^{a}$ & 2 \\
\hline LSD $(5 \%)$ & 0.6 & & 50 & & 16 & \\
\hline
\end{tabular}

LSD, least significant difference based on the error mean square with 8 df in the analysis of variance.

a,b,c Mean values in vertical columns with different superscript letters were significantly different $(P<0.02)$.

Table 6. Effects of soya-bean-based infant formulas $(4 \cdot 2 \mathrm{~g}$ protein/l) on digesta passage and nitrogen absorption in the small intestine of soya-bean-sensitive calves

(Mean values with their standard errors)

\begin{tabular}{|c|c|c|c|c|c|c|}
\hline \multirow[b]{2}{*}{ Product fed } & \multicolumn{2}{|c|}{$\begin{array}{l}\text { Small intestinal } \\
\text { transit time } \\
\text { (h) }\end{array}$} & \multicolumn{2}{|c|}{$\begin{array}{l}\text { Ileal flow-rate } \\
0-21 \mathrm{~h} \\
(\mathrm{~g} / \mathrm{h})\end{array}$} & \multicolumn{2}{|c|}{$\begin{array}{l}\text { Net } N \text { absorption } \\
\text { (\% of intake) }\end{array}$} \\
\hline & Mean & SE & Mean & SE & Mean & SE \\
\hline $\begin{array}{l}\text { Prosobee powder (Mead } \\
\text { Johnson) }\end{array}$ & $3 \cdot 5^{\mathrm{a}}$ & $0 \cdot 5$ & $99^{\mathrm{a}}$ & 22 & $-58^{a, b}$ & 28 \\
\hline Wysoy (Wyeth) & $3 \cdot 5^{\mathrm{a}}$ & 0.2 & $127^{\mathrm{a}}$ & 44 & $-94^{b}$ & 45 \\
\hline Formula $S$ (Cow and Gate) & $4 \cdot 3^{\mathrm{a}}$ & $1 \cdot 0$ & $53^{\mathrm{a}}$ & 8 & $-29^{\mathrm{a}}$ & 33 \\
\hline SMA (Wyeth; control) & $4 \cdot 0^{\mathrm{a}}$ & $0 \cdot 8$ & $69^{\mathrm{a}}$ & 14 & $-39^{a, b}$ & 16 \\
\hline $\operatorname{LSD}(5 \%)$ & 30 & & 105 & & 62 & \\
\hline
\end{tabular}

LSD, least significance difference based on the error mean square with $8 \mathrm{df}$ in the analysis of variance.

a,b Mean values in vertical columns with different superscript letters were significantly different $(P<0.02)$.

microtitre plates, titres of 8,11 and 11 for the three calves were obtained by ELISA. The results of the combined first and third feeding trials are shown in Table 5. All soya-beanbased formulas gave significantly reduced small intestinal transit times compared with that observed when a milk-based formula, SMA (control diet), was given. This decrease in transit time was accompanied by an increase in ileal flow-rates although the value obtained for Wysoy was not significantly different from the control result with SMA. N absorption values for feeds containing Prosobee powder and Wysoy were significantly lower than the control value, with Prosobee powder giving the lowest result. However, Formula $S$ gave values for $\mathrm{N}$ uptake that were not significantly different from the control. It was clear from these results that all the soya-bean-based products tested in calves could, to varying extents, 
provoke some disturbances in gut function. Therefore, the experiment was repeated giving a lower protein dose in an attempt to discriminate more precisely between the formulas. Results are shown in Table 6. No significant differences were found in small intestinal transit time and flow-rate when test and control diets were given, although there was evidence that Prosobee powder and Wysoy were causing some disturbances and Formula $\mathrm{S}$ was not. Giving feeds with a reduced level of protein $(4 \cdot 2 \mathrm{~g}$ rather than $21 \mathrm{~g}$ protein $/ 1)$, which were supplying insufficient amounts of $N$ for maintenance, led to net losses of nitrogenous constituents by the small intestine. There was no significant difference between the control and soya-bean values but the greatest $\mathrm{N}$ losses occurred when Prosobee powder and Wysoy were given, while losses on the Formula $\mathrm{S}$ diet were lower than that on the control diet.

\section{DISCUSSION}

In the present study we have compared the antigenicity of several soya-bean-based infant formulas which are commercially available in the UK. Antigenicity was evaluated in different animal models and by an in vitro assay. This approach may give a more satisfactory prediction of the potential allergenicity of foods for man than the use of a single method of assessment. An ELISA was used to identify the presence of specific soya-bean antigens, and the animals tests were used to determine the extent to which the soya-bean protein in infant formulas was capable of evoking an immune response either when injected or when given orally.

The competitive inhibition ELISA demonstrated clear differences in the levels of the two major soya-bean antigens, glycinin and $\beta$-conglycinin, in the four infant formulas that were studied. Prosobee powder gave the highest values, Wysoy and Formula $\mathrm{S}$ the lowest, and Prosobee liquid concentrate was intermediate. The glycinin assay curve for Prosobee powder (Fig. 1) was similar in shape to that for the standard (Dosoy), while the curve for Prosobee liquid concentrate differed. Similar results were obtained for $\beta$-conglycinin. Prosobee liquid concentrate is a heat-sterilized product and it interesting that in studies of cow's-milk-whey proteins (Heppell et al. 1984), heat treatment also resulted in a change in the shape of the assay curves. This was thought to reflect a reduction in the affinity for antibodies in partially denatured or heat-aggregated molecules.

In vivo studies of antigenicity were conducted in guinea-pigs, rabbits and calves. A significant difference between the antigenicity of Prosobee powder and Wysoy was seen when rabbits were injected with these formulas in CFA. The lower antigenicity of Wysoy is in agreement with the in vitro results, but it is clear that levels of glycinin and $\beta$ conglycinin below the limits of detection by ELISA were immunogenic when injected in CFA. The results in guinea-pigs also demonstrated that the formulas differed in their sensitizing capacities. However, all were capable of evoking an immune response and differences between the formulas were less marked than those observed in vitro. Nevertheless, both assessments of antigencitiy showed the same trend, with Prosobee powder being the most antigenic and Formula $S$ the least. Although the guinea-pig is a convenient animal to use for in vivo studies of antigenicity, there is no evidence that sensitization to dietary protein results in any adverse physiological problems in the gastrointestinal tract. In contrast, the preruminant calf has been shown to develop severe gastrointestinal disorders following the introduction of non-cow's-milk protein into its diet and these disorders possess many of the features of an allergic response (Kilshaw \& Sissons, $1979 b$; Kilshaw \& Slade, 1982). The three soya-bean-based formulas tested in soya-beansensitive calves were all capable of inducing intestinal disturbances which in earlier work (Pedersen \& Sissons, 1984) have been linked with levels of immunologically active glycinin and $\beta$-conglycinin in the diet, inflammatory reactions in the gut, and high titres of 
circulatory soya-bean-specific antibodies. Net $\mathbf{N}$ absorption is probably the best measure of digestive disturbances because it reflects the combined effects of endogenous losses together with changes in absorption resulting from increased rates of passage and flow of digesta. On this basis, Prosobee powder induced the most severe disturbances since its inclusion in a feed given to soya-bean-sensitive calves led to relatively higher rates of ileal digesta flow and lower absorption of $\mathrm{N}$ compared with feeds containing Formula $\mathrm{S}$ (see Table 5). However, compared with SMA, all the soya-bean-based formulas were found to be capable of inducing some disturbances in gut function. The concentration of protein $(21 \mathrm{~g} / \mathrm{l})$ in the feed was the same as that normally fed to infants as a reconstituted milk formula. However, because of the great sensitivity of the calves to antigenic soya bean, this level of protein may have been too high to show a clear distinction between the different test products. Indeed, in the second trial when the calves were challenged with the lower dose of soya-bean protein $(4 \cdot 2 \mathrm{~g} / \mathrm{l})$, Formula $S$ behaved in a closely similar manner to the cow's-milk-based formula (SMA) and gave net $\mathrm{N}$ losses which were less than the values for Prosobee powder and Wysoy (Table 6), confirming that this was the least antigenic of the soya-bean products. Thus, the three in vivo assessments of antigenicity produced essentially similar results, demonstrating differences in the antigenicity of soya-bean-based formulas which broadly correlated with the immunochemical measurements.

It is conceivable that industrial processing, and digestion within the gastrointestinal tract, while destroying some native antigenic determinants, may lead to the creation of new specificities. Studies of Spies et al. (1970), Haddad et al. (1979) and Wright \& Rothberg (1971) have shown that hydrolysis of cow's-milk protein with pepsin and trypsin can generate peptides with new antigenic determinants. However, the importance of such antigenic fragments in oral sensitization is unclear. Wright \& Rothberg (1971) showed that rabbits did not become immunized to new internal determinants uncovered by digestion, and Dosa et al. (1979) demonstrated that peptic fragments of bovine serum albumin were immunosuppressive. Serum from a soya-bean-allergic individual was shown to give positive skin reactions in passive transfer tests using native soya bean as the challenge antigen (Ratner et al. 1955). Moreover, Kilshaw et al. (1986) presented evidence that although ovalbumin is ingested by man largely in a denatured form, the serum antibody response is stimulated mainly by topographic epitopes of the native molecule. There is evidence that during storage or heating of some foods, allergenicity may increase (Bleumink, 1970). However, this appears to be the result of non-enzymic browning (Maillard) reactions rather than generation of new antigenic specificities (reviewed by Bleumink, 1979). More recently, McLaughlan et al. (1981) and Heppell et al. (1984) showed that heat treatment of cow'smilk protein reduced its oral sensitizing capacity in parallel with a reduction in the level of native antigenic determinants. The digestibility of soya beans in calf feeds can be improved by processing methods which reduce the levels of antigenic glycinin and $\beta$-conglycinin (Stobo et al. 1983). Poor digestibility was thought to result from an allergic reaction to antigenic soya bean. Thus, there is no clear evidence that any secondary antigenic determinants which may be created by industrial processing or gastrointestinal digestion have importance in stimulating an immune response by the oral rcute. In the present study we also were unable to demonstrate any new specificities resulting from processing of soyabean-based infant formulas which were capable of evoking an oral immune response. Titres of soya-bean-specific antibody in guinea-pig sera measured on plates coated with the infant formulas were very similar to titres obtained on plates coated with unprocessed soya bean (Dosoy). Also, guinea-pigs fed on and challenged with the soya-bean-based products showed differing levels of anaphylactic reactivity which broadly correlated with the serum antibody response to native glycinin and $\beta$-conglycinin. We therefore believe that an assessment of the level of native antigenic determinants may give some indication of the 
potential allergenicity of soya-bean-based formulas, although this can only truly be validated by clinical trials.

Our results illustrate the importance of including some in vivo studies when assessing antigenicity, since on the basis of the in vitro results alone, Wysoy and Formula $S$ might have been considered to be non-antigenic. Differences between the results obtained in the feeding experiments and by immunochemical assessments could be due to the presence in soya-bean of antigenic material other than glycinin and $\beta$-conglycinin. Also, digestion could have had an effect on antigenicity since, while it may lead to the destruction of antigenic sites, it could equally expose sites within aggregates that may have been formed during industrial processing. Therefore, oral presentation of antigenic material is probably the best method of comparing the potential allergenicity of foods for man. In previous studies (Heppell et al. 1984) we have discussed the use of the guinea-pig model for this purpose and our present results further demonstrate its value. However, the calf model is also useful because it facilitates the study of potentially allergenic products in an animal which can suffer from a food allergy and it allows repeated determinations to be made in the same animal. It also provides a model where the method of sensitization and challenge is by feeding a liquid diet in which the infant formula provides all the protein. This resembles the situation for babies who have become allergic to soya bean.

In conclusion, the four soya-bean-based formulas were shown to differ significantly in their antigenicity. Differences observed in vitro were reflected in vivo with Prosobee powder being the most highly antigenic and Formula $S$ the least. However, it was clear that in vivo and in vitro results did not entirely correspond, thus stressing the value of in vivo assessments. It is important to consider these differences in antigenicity when interpreting the results of clinical trials. From studies of the serum antibody response of bottle-fed infants, Eastham et al. (1978) concluded that soya-bean protein is at least as antigenic as cow's-milk protein. The soya-bean-based formula used in this earlier trial was Prosobee. It is possible that their conclusion might have been different if one of the soya-bean-based formulas which gave lower antigenicity in our study had been used instead of Prosobee.

The authors thank S. M. Banks and A. Cosway for technical assistance, the staff of the animal unit, and also Dr P. J. Kilshaw for advice in raising antisera to the infant formulas in rabbits.

\section{REFERENCES}

Bleumink, E. (1970). World Review of Nutrition and Dietetics 12, 505-570.

Bleumink, E. (1979). In Immunology of the Gastrointestinal Tract, pp. 195-213. [P. Asquith and P. G. H. Gell, editors]. Edinburgh: Churchill Livingstone.

Dosa, S., Pesce, A. J., Ford, D. J., Muckerheide, A. \& Michael, J. G. (1979). Immunology 38, 509-517.

Eastham, E. J., Lichauco, T., Grady, M. I. \& Allan Walker, W. (1978). Journal of Pediatrics 93, 561-564.

Glaser, J. \& Johnstone, D. E. (1953). Journal of the American Medical Association 153, 620-622.

Haddad, Z. H., Verma, S. \& Kalra, V. (1979). Journal of Allergy and Clinical Immunology 63, 198.

Halpern, S. R., Sellars, W. A., Johnson, R. B., Anderson, D. W., Saperstein, S. \& Reisch, J. S. (1973). Journal of Allergy and Clinical Immunology 51, 139-151.

Halpin, T. C., Byrne, W. J. \& Ament, M. E. (1977). Journal of Pediatrics 91, 404-407.

Heppell, L. M. J., Cant, A. J. \& Kilshaw, P. J. (1984). British Journal of Nutrition 51, 29-36.

Heppell, L. M. J. (1985). In Immunoassays in Food Analysis, pp. 115-123. [B. A. Morris and M. N. Clifford, editors]. London: Elsevier Applied Science Publishers.

Hunt, J. N. \& Stubbs, D. F. (1975). Journal of Physiology 245, 209-225.

Kilshaw, P. J., McEwan, F. J., Baker, K. C. \& Cant, A. J. (1986). Clinical and Experimental Immunology 66, $481-489$.

Kilshaw, P. J. \& Sissons, J. W. (1979a). Research in Veterinary Science 27, 366-371.

Kilshaw, P. J. \& Sissons, J. W. (1979b). Research in Veterinary Science 27, 361-365.

Kilshaw, P. J. \& Slade, H. (1982). Research in Veterinary Science 33, 305-308.

Kjellman, N.-I. M. \& Johansson, S. G. O. (1979). Clinical Allergy 9, 347-358. 
McLaughlan, P., Anderson, K. J., Widdowson, E. M. \& Coombs, R. R. A. (1981). Archives of Disease in Childhood 56, 165-171.

May, C. D., Fomon, S. J. \& Remigio, L. (1982). Acta Paediatrica Scandinavica 71, 43-51.

Pedersen, H. E. \& Sissons, J. W. (1984). Canadian Journal of Animal Science 64, 183-184.

Perkkiö, M., Savilahti, E. \& Kuitunen, P. (1981). European Journal of Pediatrics 137, 63-69.

Powell, G. K. (1978). Journal of Pediatrics 93, 553-560.

Ratner, B., Untracht, S., Crawford, L. V., Malone, H. J. \& Retsina, M. (1955). American Journal of Diseases of Children 89, 187-193.

Sissons, J. W. (1983). Journal of Dairy Research 50, 387-395.

Sissons, J. W. \& Smith, R. H. (1976). British Journal of Nutrition 36, 421-437.

Sissons, J. W., Smith, R. H. \& Hewitt, D. (1979). British Journal of Nutrition 42, 477-485.

Spies, J. R., Stevan, M. E., Stein, W. J. \& Coulson, E. J. (1970). Journal of Allergy 45, $208-219$.

Stobo, I. J. F., Ganderton, P. \& Connors, H. (1983). Animal Production 36, 512-513.

Voller, A., Bidwell, D. E. \& Bartlett, A. (1976). Bulletin of the World Health Organization 53, 55-65.

Wright, R. N. \& Rothberg, R. M. (1971). Journal of Immunology 107, 1410-1418. 